\title{
Peritoneal Infection
}

National Cancer Institute

\section{Source}

National Cancer Institute. Peritoneal Infection. NCI Thesaurus. Code C78540.

An infectious process affecting the peritoneum. 